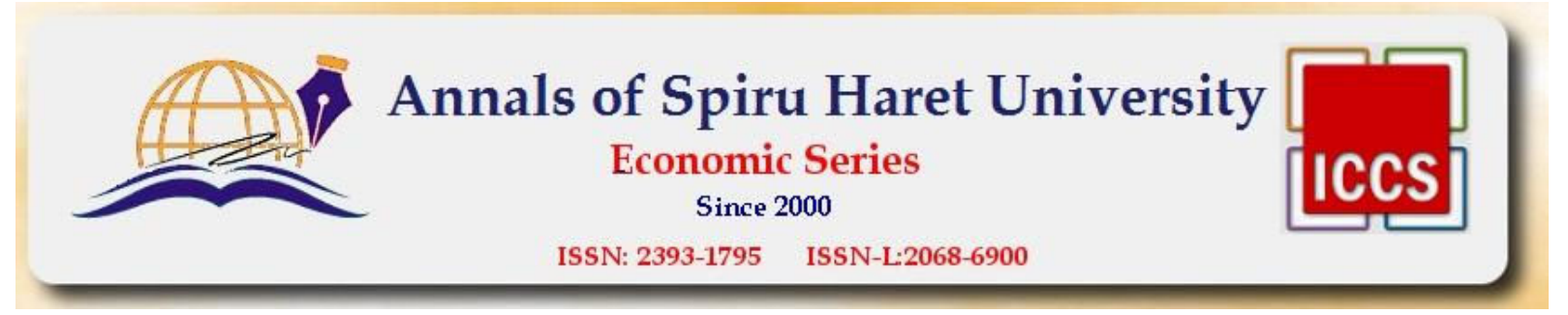

Issue 4/2016

\title{
KNOWLEDGE AS INVESTMENT IN HUMAN RESOURCES TO INCREASE THE COMPANY SUCCESS
}

\author{
Oriana NEGULESCU \\ "Spiru Haret" University, Faculty of Juridical, Economic and Administrative Sciences, Brașov, \\ Turnului Street, no. 7, Braşov, Romania, Tel.: +40212421208, Fax: +40212420781, Email: \\ bellatrix360@yahoo.fr
}

\begin{abstract}
In this era, characterized by rapid changes in information and communication technologies and the increasing competition on the global market, the main factor of strategic development of the modern successful company is the development of strategic resources. The most important strategic resource is the people's expertise that is bringing competitive advantage to the company. The employees' knowledge accumulation is probably the main tool the management has to consider in designing strategies for company's growth. However, the employees' knowledge is contributing to the knowledge-based company, as a factor of success. This paper is aiming to emphasize the main concepts regarding the knowledge-based concept, the profile of a knowledgebased company, the importance of employees' knowledge accumulation for the company's development and to consider the knowledge as being an investment by training. The return of investment in human resources knowledge is finally analyzed.
\end{abstract}

Keywords: strategic resources, knowledge-based company, investment in human resources, return on investment.

JEL Classification: D83, D87, M19, M21, M53

\section{Introduction}

In the last decades of the $20^{\text {th }}$ century the information and communication technology has been rapidly developed and as a consequence the people's digital skills. Whether the people has been considered to be the companies' best resource, in the first decades of the $21^{\text {st }}$ century the expertise in bringing knowledge to the companies became the most valuable resource to bring competitive advantage.

This paper is aiming to underline the importance of people's knowledge accumulation as investment in a knowledge-based company. The paper covers in brief the main concepts of knowledge, the profile of the knowledge-based company, the concept of knowledge accumulation by training as investment and finally the return on investment in human resources knowledge, by using the conceptual ideas of different authors that have been cited and the own view on the mentioned topics.

\section{What is knowledge?}

Drucker (1998) considers the knowledge is the ability to know what to say and say it well. He considers the current concept of knowledge as being knowledge which "proves itself in action" and is focused on results.

The knowledge has different forms (Doval, 2008), such as:

- Explicit knowledge: books, papers, databases, videos, etc.;

- Implicit knowledge: in people's mind and could be explained;

- Tacit knowledge: in people's mind and difficult to be explained.

But, the tacit knowledge is transforming in explicit knowledge, the explicit knowledge in tacit knowledge and so on (Nonaka \& Takeuchi, 1995). In this respect, Stevens (1998) describes codified knowledge as being able to be reduced to information (the know-what) and tacit knowledge as including skills such as insight, creativity and judgment (the know-how). 


\section{2 Annals of Spiru Haret University Economic Series Since 2000 \\ ISSN: 2393-1795 ISSN-L:2068-6900}

\section{Issue 4/2016}

Different authors point out knowledge or knowledge characteristics in different ways, all being relevant to understand the concept, such as:

- knowledge doesn't exist in nature as such; it is a human and cultural product. knowledge is a self-expanding resource, but can only be artificially transformed into a scarce resource (Fucs, 2004);

- knowledge doesn't last forever; it become obsolete in the context of use (Howitt, 1998);

- knowledge is a key resource of companies (Scarso \& Bolisani, 2010).

Nevertheless, knowledge is a valuable intangible resource for any company being related to innovation and being able to develop a framework of human capital and information and communication technology and that hardly ever may be measured.

\section{Knowledge-based company}

A knowledge-based company can be defined as a company that is focused on the use of ITC and on assessing its employees upon their expertise to innovate, applies the knowledge and develops the intellectual capital in order to gain competitive advantage, profit or benefits.

Very often the most valuable knowledge that an organisation has is in the heads of its people, and those of its stakeholders, especially customers (Tocan, 2012). But, in all strategic processes in the firms based on knowledge, not all knowledge has the same role and impact (Nicolescu, 2011).

In such organizations, the people invent and create knowledge (ideas, experiences, the training results) and transform the knowledge into new products, services, technologies, projects that are offered in an accelerated pace to the market (Nonaka, 1998).

The methods used to create knowledge in a company could be grouped into four types of conversion (Neagu, 2009): (1) socialization, such as shared experience, on-the-job training, informal meetings, apprenticeship, joint activity, etc.; (2) externalization, such as dialogue and self-reflection; (3) combination (meetings and telephone conversation, presentations, ITC use); (4) internalization (learning-by-doing, simulations/experiments, reflections with others, etc.).

A company may become knowledge-based by using the Knowledge enterprise building model, a conceptualization of the "Knowledge growth model" (Burton-Jones, 1999), following six stages (fig. no. 1):

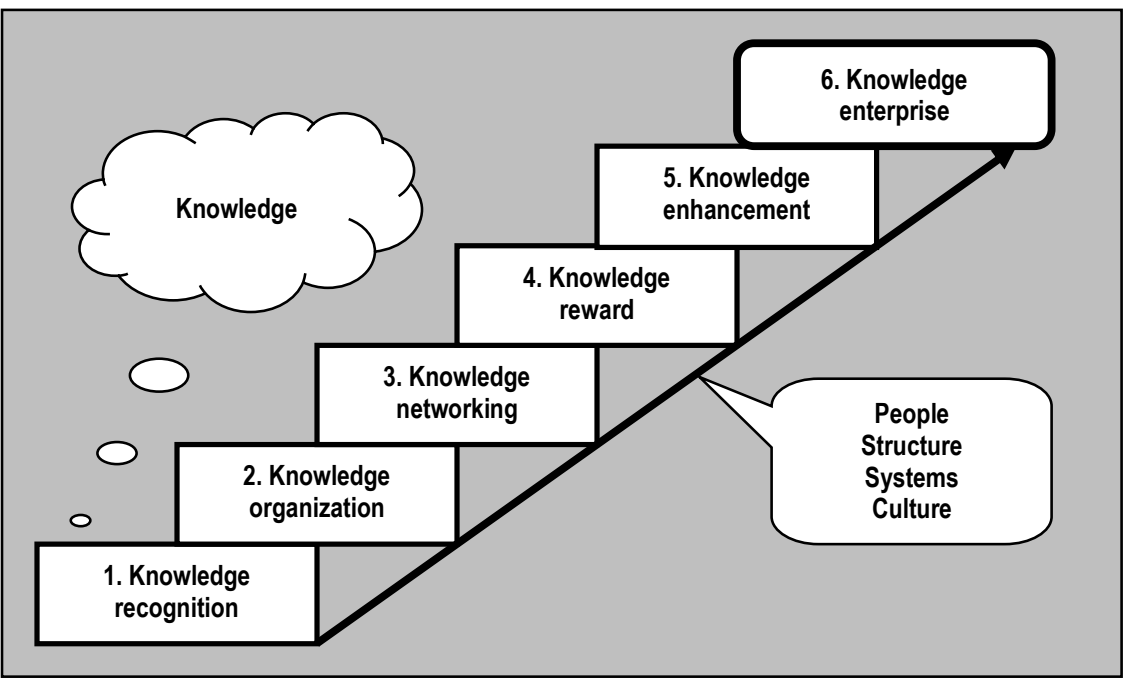

Figure no. 1. Knowledge enterprise building model

Source: Adapted from Burton-Jones, 1999 


\section{Annals of Spiru Haret University \\ Economic Series \\ Since 2000 \\ ISSN: 2393-1795 ISSN-L:2068-6900}

Issue 4/2016

(1) Knowledge recognition: creation of corporate awareness of the importance of knowledge as a factor of production.

(2) Knowledge organization: characterized by reductions in middle management layers accompanied by progressive externalization of non-core functions and internalization of core functions.

(3) Knowledge networking: characterized by the diffusion of edition making and increased use of cross-functional teams. focus.

(4) Knowledge reward: realigning the reward system with internal structure and knowledge

(5) Knowledge enhancement: marked by increased investment in R\&D and training.

(6) Knowledge enterprise: knowledge management and business management have fused.

In the process of building the knowledge enterprise the structure, systems and organizational culture are changing and its people are adapting to the new concept.

\section{The profile of a knowledge-based company}

The main characteristics of the knowledge-based economy that could be transferred to any company that is willing to be a knowledge-based one are grouped on three dimensions (Trewin, 2002):

(1) Innovation and entrepreneurship

- research base and potential for knowledge creation;

- knowledge creation with commercial potential (this includes invention and patenting activity);

- knowledge networks and flows;

- entrepreneurial activity, referring to the creation of new, fast-growing businesses.

(2) Human capital

- stock of skilled people (education and skill levels of the population and the potential stock of qualified people);

- flow of skilled people (this characteristic looks at knowledge workers, the level of educational attainment of the labour force, the extent of employees' training and human capital loss/gain from the economy);

- investment in human capital (refers to expenditure on education and training by government and business);

- lifelong learning and access to education and training.

(3) Information and communication technology

- ICT infrastructure and access;

- business and government use of ICT (examines the penetration of ICT into business and government processes);

- ICT skill base (refers to the share of ICT workers in the labour force, as well as covering skill shortage issues.

A knowledge-based organization is made up of four characteristics that can be summarized as process, place, purpose and perspective (Zach, 2003).

- Process refers to the activities within an organization, some of which are directly involved with making a product or selling a service and others that are ancillary but no less important.

- Place refers to the boundaries of the organization, which for the purposes of sharing and creating knowledge often go beyond traditional legal boundaries.

- Purpose refers to the mission and strategy of the organization - how it intends to serve its customers profitably. 


\section{Annals of Spiru Haret University \\ Economic Series \\ Since 2000}

ISSN: 2393-1795 ISSN-L:2068-6900

Issue 4/2016

- Perspective refers to the worldview and culture that influences and constrains the decisions and actions of an organization.

A knowledge-based enterprise derives knowledge from various sources that include customer, competitor, product, process, financial and people knowledge (Kotelnikov, 2016).

The organizations that understand their operational dependencies on human capital (talent, knowledge, etc.) are succeeding because they see things differently (Rhodine, 2015):

- they understand that success falls on the technical enterprise, and that the technical enterprise depends on talent and knowledge;

- they also understand that their knowledge workers - those individuals engaged in the acquisition, analysis, and manipulation of information versus the production of goods or services - are a critical component of organizational success;

- knowledge, in turn, depends on reliable information as a feedstock;

- successful companies recognize this dependency and work hard to equip them with information.

Briefly speaking, a knowledge-based company is characterized by the following features that are bringing success:

- strategic resources: highly-skilled workers, know-how, knowledge, information, intellectual property;

- strategic competencies: high level of technology, innovation, market opportunities to customers, investment in knowledge and people, knowledge diffusing and using competitive advantage capitalization.

The traditional organizations are facing on the market the competitive advantage of the learning organizations and the knowledge-based organizations that are performing due to the knowledge (Doval, 2014).

\section{Considering the knowledge as being an investment by training}

The investment in knowledge is defined as the public and private spending on higher education, expenditures on research and development, and investment in computer-based and information systems, spending on education and skills development clearly critical to the growth of a modern workforce (Gogoforth, 2010).

Training presents a prime opportunity to expand the knowledge base of all employees, but many employers find the development opportunities expensive. Despite the potential drawbacks, training and development provides both the company as a whole and the individual employees with benefits that make the cost and time a worthwhile investment (Tyagi, 2015).

The human resources expenses include the training of managers for job interviews, performance evaluation and self-assessment forms development and training of employees to complete selfassessment forms, job analysis and job descriptions and the activities monitoring.

All large firms are engaged in training and continuous training of staff by scheduling, organizing and conducting training programs and programs for coaching, through which employees or those promoted to higher positions are assisted and guided to get the expected performance of the company's management. The accumulation of knowledge involves complex cognitive processes: perception, communication, association and reasoning (Cavell, 2002).

Although the costs incurred for human resources' training involve, among other things: expenditure on salaries of lecturers or instructors; administrative expenses (room rental, catering); costs of advertising media; expenses of materials for disseminating knowledge (CDs, videos, films, brochures, books, etc.), however, investment in human resources benefits are obvious: higher productivity, quality of the work and products/services, wages, workers' moral and satisfaction, loyalty to the company. 


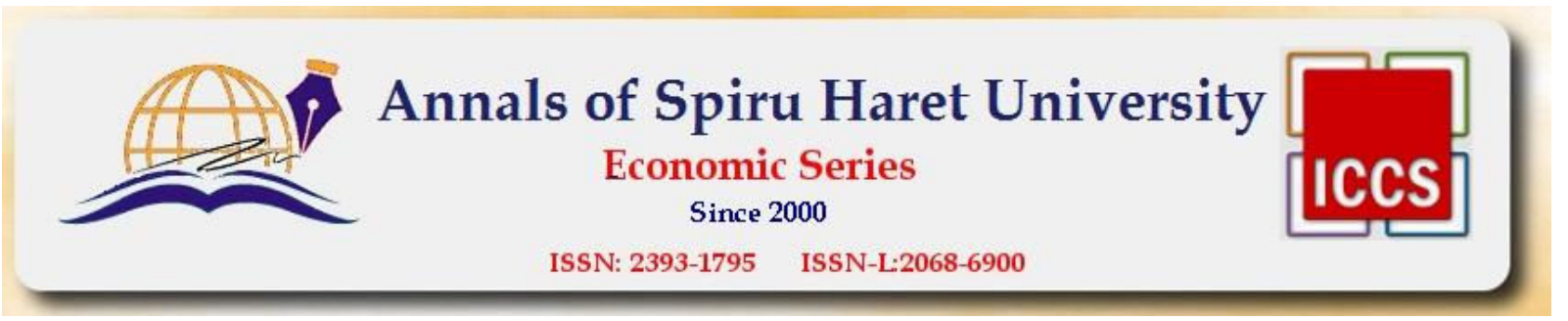

Issue 4/2016

In fact, expenditure on training human resources is an investment in intangible capital of the company.

Knowledge-based businesses generate cash flows from investment in intangibles rather than from physical assets and labour. Investment in intangible knowledge-based assets includes R\&D, design, brand equity, software, and human and organisational (relational) capital. This is both difficult to value and does not provide clear collateral for investors (Wilson \& Wright, 2015).

The rate of return on investment may be measured by analysing the change in skills and competences of each individual and the impact on company's performance due to investments in training. One analysis of a large US manufacturing firm revealed that an increase in training expenditure yielded a rate of return for the company of 20 to 35 per cent (Bartel, 1995). Other studies have found that the beneficial effects of enterprise training depend on collateral investment in technology (Lynch, 1995).

Using quantifiable metrics improves the credibility of human resources as a profession, and allows upper management to identify specific, measurable ways that human resources services benefit the organization. To calculate the return on investment of human capital, the organization's net revenue (gross revenue after deducting operating expenses, salaries and benefits) is divided by the cost of salaries and benefits. To calculate the return on investment of a particular training program, the value of the specific program has to be calculated, then to divide it by the costs of implementing the program (Benjamin, 2016).

In order to estimate the optimal investment for workforce training the accumulation theory and the Cobb-Douglas production function are useful (Hartu, 1995).

\section{The accumulation theory}

The factors involved in the investment for the workforce training using the accumulation theory are: the capital, investments, the capital amortization coefficient, the accumulation rate, the accumulation fund and the yield obtaind from the investments operation. The capital accumulation is usually done through investment and while the capital is used, the capital amortization occurs. Nevertheless, the accumulation fund leads to the investments capital increase. Or, labour is a factor in the revenue growth and the workforce growth is determined by two classic ways:

- quantitatively, by recruiting additional number of employees;

- qualitatively, through training, raising the level of training the existing workforce.

Therefore, the accumulation fund acquires precise destinations: equity investments (technologies, equipment, etc.) and investment in workforce. When the growth rate of the labour force is approximately constant, the optimal investment for workforce training is obtained.

\section{Cobb-Douglas production function}

The turnover is a function of expenditure on staff training and investment expenses, expenses corrected with specific coefficients. From here, the necessary investments in the human resources' training, and the impact of the training investment on the turnover growth and, generally, the increasing of the company's performance are determined. Therefore, every increase of the investment budget for human resources training considering constant wages leads to the increase of the turnover and to the gradual decline on the share of spending on training in total turnover. But, the training investment is increasing the employees' knowledge and thus their wages, with negative consequences on the company's profit. The balance is to be realized between the increased expenses with the training programs and the increase of productivity and products/services quality. 


\section{Annals of Spiru Haret University \\ Economic Series \\ Since 2000}

ISSN: 2393-1795 ISSN-L:2068-6900

Issue 4/2016

\section{Conclusions}

The knowledge is an intangible resource for any company and the most valuable resource is the highly skilled employees.

The expenses with the knowledge accumulation by training programs may be considered investment because they have positive impact on the company's turnover and profit and, in addition, they bring more benefits like employees' and customers' satisfaction, higher productivity and quality and not the last elevate the employees' stability and loyalty towards the company.

A knowledge-based company well equipped with information and commu-nication technology and highly skilled employees and providing programs of human resources training is able to build and develop strategic competences that are conducting it to success.

Nevertheless, the investment in knowledge is conducting to the company's long-term growth, having in view the fact that the returns are increasing and the company becomes more competitive.

This paper may be a useful reference for any company and it may be developed in terms of methods to evaluate different other forms of knowledge accumulation rather than training programs (such as coaching, learning-by-doing and so on).

\section{References}

1. Hârtu, C., Simularea strategiilor de creştere economică (Bucureşti: Editura Pacifica, 1995), p. 56.

2. Cavell, S., Knowing and Acknowledging, Must We Mean What We Say? (Cambridge University Press, 2002), pp. 238-266.

3. Nonaka, I. and Takeichi, H., The Knowledge-creating company: How Japanese companies create the dynamics of innovation (Oxford University Press, UK, 1995).

4. Drucker, P. F., "From Capitalism to Knowledge Society", in The Knowledge Economy, Ed. D. Neef (Butterworth-Heinemann, Boston, 1998).

5. Howitt, P., "On Some Problems in Measuring Knowledge-Based Growth", in The Knowledge Economy, Ed. D. Neef (Butterworth-Heinemann, Boston, 1998).

6. Stevens, C., "The Knowledge-Driven Economy", in The Knowledge Economy, Ed. D. Neef (Butterworth-Heinemann, Boston, 1998).

7. Burton-Jones, A., Knowledge capitalism. Business, work, and learning in the new economy, part 3 (Oxford Scholarship Online, 1999), pp. 167-169.

8. Bartel, A., "Training, wage growth and job performance: evidence from a company database", Journal of Labor Economics, Vol. 13 (1995).

9. Doval, E., "Organization's competitive advantages related to societal knowledge management", Analele Universitatii Oradea, Seria: Stiinte economice, Tom XVII No. 1/2008, pp. 208214.

10.Doval, E., "Changing the strategy: learning or knowledge based organization", Review of General Management, ISSN 1841-818x, Vol. 20, iss. 2, pp. 138-149 (2014).

11. Fuchs, C., "Knowledge management in self-organizing social systems", Journal of Knowledge Management Practice (May 2004).

12. Nicolescu, O., "The specific of knowledge based strategies", Review of General Management (Volume 14, Issue 2, Year 2011), pp. 36-55.

13. Nonaka, I., "The knowledge-creating company", in Harvard Business Review on Knowledge Management, (USA, 1998), pp. 21-45. 

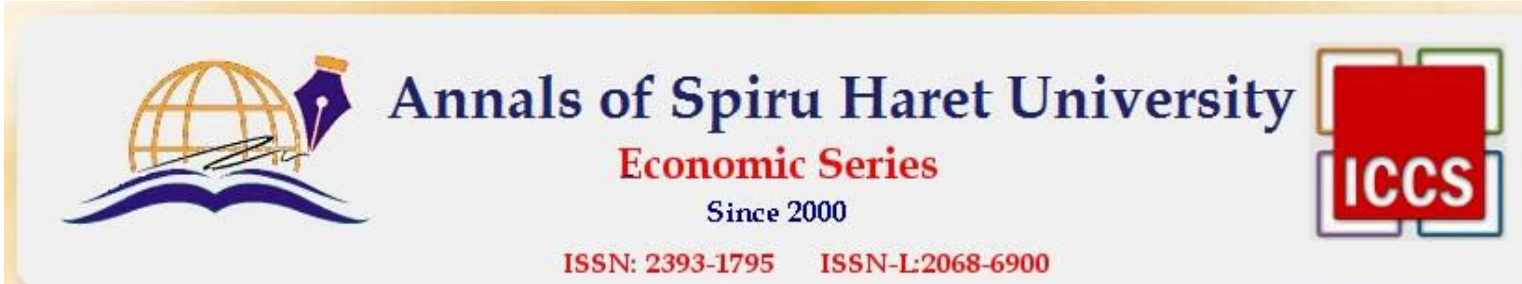

Issue 4/2016

14. Scarso, E \& Bolisani, E., "Knowledge-Based Strategies for Knowledge Intensive Business Services: a multiple case study of computer service companies", Electronic Journal of Knowledge Management, Volume 8, Issue 1 (2010), pp. 151-160.

15. Tocan, M.C., "Knowledge Based Strategies for Knowledge Based Organizations", Journal of Knowledge Management, Economics and Information Technology, Issue 6, December 2012, website article, http://www.scientific-papers.org/wp-content/files/1324_Madalina_TOCAN_Knowledge_based strategies_for_knowledge_based_organizations.pdf.

16. Zach, M.H., "Rethinking the Knowledge-Based Organization", MITSloan Management Review, July 15, 2003, http://sloanreview.-mit.edu/article/rethinking-the-knowledgebasedorganization/.

17. Lynch, L.M., Employer-provided Training in the Manufacturing Sector: First Results from the United States, paper presented at the World Bank Conference on "Enterprise Training Strategies and Productivity", Washington, DC, June, cited in The knowledge-based economy, Organization for economic co-operation and development, Paris, 1996.

18. Benjamin, T. (2016), What is a return on investment in human resources? Website article, Small Business, http://smallbusiness.chron.com/return-investment-human-resources-45590.html.

19. Gogoforth, R.R. (2010), Knowledge-Based Industries and Investment, Capital Formation Institute, Inc., website article, http://www.cfi-institute.org/VP\%20-\%20KnowledgeBased\%20Industries\%20and\%-20Investment\%20-\%20Goforth.html.

20. Kotelnikov, V. (2016), Knowledge-based Enterprise. Knowledge Management as a Key to Sustainable Competitive Advantage, website article, http://www.1000ventures.com/business_guide/crosscuttings/knowledge based -enterprise.html.

article,

21. Neagu, C.D. (2009), Knowledge based organization. An identification model, website school/summerschool2009/IFIP2007POST/papers/S10_P1_Denisa_Neagu.pdf.

22. Rhodine, S. (2015), Building the Knowledge-Based Enterprise, website article, Dec., 3, 2015, Supply Chain Learning Center, http://www.sdcexec.com/article/12135461/building-theknowledge-based-enterprise.

23. Tyagi, S. (2015), Training is an investment in knowledge capital, 11 May 2015, website article, Linkedin, https://www.linkedin.com/pulse/training-investment-knowledge-capital.

24. Trewin, D. (2002), Discussion Paper: Measuring a Knowledge-based Economy and Society - An Australian Framework, 1375.0, Australian Bureau of Statistics (ABS), Canberra, http://www.abs.gov.au/ausstats/abs@.nsf/.

25. Wilson, N. \& Wright, M. (2015), The Equity Gap and Knowledge-based Firms: Executive Summary, July 8, 2015, website article, p. 2-3, https:/www.gov.uk/government/uploads/system/uploads/attachment_data/file/442573/Equity gap_report_exec_summary_030715_final.pdf. 
